\title{
Vibrio cholerae: General Knowledge and Epidemiological Aspects
}

\author{
Vicento Diabeno, Erick Kamangu \\ Department of Basic Sciences, Faculty of Medicine, University of Kinshasa, Kinshasa, DRC \\ Email: erick.kamangu@unikin.ac.cd, vicento.diabeno@unikin.ac.cd
}

How to cite this paper: Diabeno, V. and Kamangu, E. (2019) Vibrio cholerae: General Knowledge and Epidemiological Aspects. Open Access Library Journal, 6: e5571.

https://doi.org/10.4236/oalib.1105571

Received: July 2, 2019

Accepted: July 28, 2019

Published: July 31, 2019

Copyright $\odot 2019$ by author(s) and Open Access Library Inc.

This work is licensed under the Creative Commons Attribution International License (CC BY 4.0).

http://creativecommons.org/licenses/by/4.0/

\section{Open Access}

\begin{abstract}
Cholera is an infectious diarrheal disease, highly contagious transmitted by a gram-negative bacteria, Vibrio cholerae. The infectious strain is divided into two biotypes (El Tor and Classical) based on their phenotypic characteristics and three serotypes (Inaba, Ogawa, Hikojima) according to the antiserum agglutination test. The Hikojima serotypes form is very rarely found during an epidemic. To date, several studies have shown that the CTX phage $\phi$ which is a vibriophage, confers on the bacterium its infectious nature. Through its lysogenic cycle, it converts the bacterial host from a non-pathogenic strain to a pathogenic strain, thereby providing virulence genes to the bacterial host. In 2011, several cases of cholera were reported worldwide, and in the Democratic Republic of Congo, the first cases of cholera were identified in 1994 following the displacement of Rwandan refugees in the town of Goma, bordering Rwanda. Since then, cholera has become endemic in this region. In 2017, several cases of cholera have been reported in several provinces of the Democratic Republic of Congo including Kinshasa. Hygienic measures must be taken into account to fight effectively against the disease. Strengthening the capacity of laboratory staff, the establishment of rapid molecular diagnostic tools is necessary for proper care of people living in areas likely to develop the cholera epidemic.
\end{abstract}

\section{Subject Areas}

Public Health

\section{Keywords}

Cholera, Vibrio cholerae, Bacteriophage, Epidemiology, DRC

\section{Introduction}

Cholera is an acute diarrheal disease. It is often associated with Low-income (LIC) Countries where it can cause mortality and significant economic losses, 
and even be endemic in given regions. Severe dehydration and electrolyte imbalance can result in $50 \%$ of untreated cases due to constant diarrhea leading to death [1]. Vibrio cholerae, the bacterium that is the etiological agent of cholera, is transmitted by water and food contaminated with faeces [2]. Cholera is considered endemic in a region where the bacteria live in the natural environment and outbreaks have occurred independently of imported cases [3]. Cholera can become endemic in a region through different pathways that depend on local environmental conditions. Generally, the collapse of sanitation and water supply infrastructure is the main cause of cholera outbreaks [4]. Recently, multidrug-resistant Vibrio cholera species have been reported [3] [5]. In addition, the interaction between the water-borne bacterium, the human host and the environment should be given special attention in developing strategies for the management and eradication of cholera [2].

\section{Taxonomy and Classification}

Cholera is an infectious diarrheal disease, of epidemic origin, of bacterial origin, transmitted through the digestive tract. It is a component par excellence of faecal danger, and a real emergency in public health. It is the privileged companion of natural disasters and situations of conflict that are accompanied by massive displacement of populations. However, it can occur in a context of political stability and in the absence of any natural calamity, when the socio-economic conditions of populations and those of the environment are favorable to its development [6]. $V$. cholerae 01 has two disctinted biotypes (Classic and El Tor) and each biotype has three serotypes: Ogawa, Inaba and Hikojima. Serogroups other than 01 and 0139 are not associated with cholera and may cause sporadic cases and are collectively known as $V$. cholerae non-01 and non-0139. Three non-01 serogroups that have been associated with major events are 037 [7] 075 [8], and 0141 [9]. Recent studies have shown that serogroup 0139 is a derivative of the prototype of the El tor biotype strain [10]. Additional variants of the El tor prototype, such as the Matlab strain [11], the Mozambique strain [12], and the El tor strain have been modified [13], and reported. The modified variant of the El tor strain in which the B subunit of cholera toxin is currently of the classical type generally dominates.

\section{Vibrio cholerae and Phage CTX $\Phi$}

Most bacteriophages are harmful to the metabolism of their host. However, phages also participate in the horizontal transfer of genes among bacteria because the genome keeps the port of genes other than those strictly required for their life cycle. This can be very beneficial to the bacterial host. Indeed, many bacterial virulence factors are associated with phage-like DNA sequences. Strikingly, the exotoxins produced by many pathogenic bacteria are encoded in the lysogenic phage genome. This is particularly the case in Bordetellaavium, Clostridium botulinum, Corynebacteriumdiphtheriae, Escherichia coli, Pseudomonas aeruginosa, Shigelladysenteriae, Staphylococcus aureus and Streptococcus 
pyogenes. The prophages integrated by these bacteria benefit from the multiplication of their host in the environment which is then favored by the virulence factors provided to their host [14].The study of Vibrio cholerae, the agent of the fatal diarrheal disease of cholera, provides a fascinating case of such co-evolution of bacterium-phage. V. cholerae is the host for a variety of phages, commonly known as vibriophage, which may be lytic or non-lytic, virulent or moderate [15]. On one hand, predation of $V$. cholerae phage has been reported to be a factor influencing seasonal epidemics of cholera [16]. In contrast, one of the major factors of $V$. cholerae virulence is encoded in the genome of an integrated CTX $\phi$ prophage [12] [17]. In addition, there are variants of $\mathrm{CTX} \phi$ phage that contribute to the genetic diversity of epidemics causing cholera strains [18] [19].

\section{Vibrio and Bacteriophage: Origin of CTX $\Phi$}

CTX $\phi$ is a filamentous bacteriophage specific for Vibrio cholerae that was first identified in 1996 [17]. The CTX genome includes the genes that encode cholera toxin, an $\mathrm{AB} 5$ toxin subunit secreted by $V$. cholerae during its development in the small intestine [20]. The activity of the cholera toxin greatly accounts for the deep secretory diarrhea that is characteristic of cholera. Therefore, the acquisition of CTX $\phi$ was a key event in the emergence of a pathogenic $V$. cholerae. Virulence factors are frequently encoded in mobile genetic elements such as phages and plasmids [21]. A number of features of the CTX $\phi$ genome suggest that the $\operatorname{ctxAB}$ genes were acquired by a CTX $\phi$ ancestor $(\operatorname{preCTX} \phi)$ from an unknown source [17] [22]. The percentage of GC of the ctxAB genes (38\%) is different from that of the rest of the CTX $\phi$ genome (40\%) (Figure 1).

CT production is induced by two promoters: the PrstA promoter which is -5 $\mathrm{kb}$ upstream from ctxA is required for $\mathrm{CTX} \phi$ virion synthesis but can extend into $c \operatorname{AB}$, and the PctxAB promoter is immediately upstream of ctxAB. In addition, $V$. cholerae strains carry CTX prophage sequences that do not encode the ctxAB genes that have been identified [23]. This propagative precursor CTX (preCTX) also produces the Replicative Form (RF) of their genomes that are very similar to the CTX $\phi$ genome RF but they do not carry the genes of the ctxAB. Molecular analysis of these preCTX plasmids revealed that they also missed the upstream control region normally found on the 5'side of $\operatorname{ctxA}$, as well as the region of the ctxAB promoter encoding sequences. These observations suggest that a preCTX simultaneously acquired the $\operatorname{ctx} \mathrm{AB}$ genes and their regulatory sequences. It has been proposed that in the event that leads to the acquisition of ctxAB genes by a preCTX $\phi$, the integration of the $\operatorname{preCTX} \phi$ genome occurred next to the ctxAB genes carried by an unknown organism, and because the CTX virion production occurs by rolling circle replication of the chromosome, ctxAB genes and regulatory sequences were acquired from the unknown source by imprecise replication of the prophage [24] [25]. The acquisition of ctxAB genes by pre-CTX $\phi$ has increased its ability since CTX $\phi$ confers a selective advantage to its $V$. cholerae host by producing CT; the action of enterotoxin 


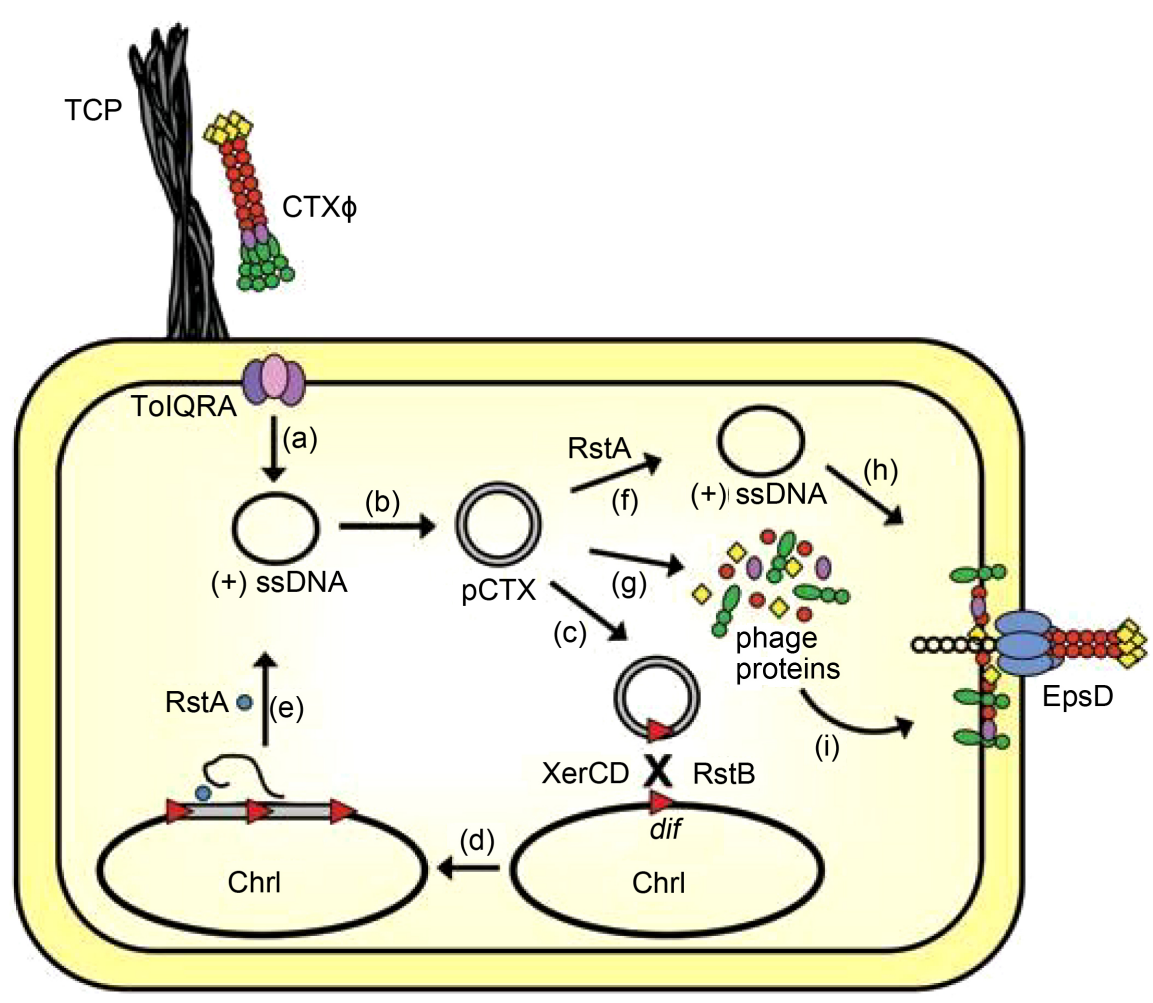

Figure 1. Schematic life cycle representation of $V$. cholerae. Source: CTX $\phi$ and vibrio cholerae exploring a newly recognized type of phage-host cell relationship. (a) CTX $\phi$ infects $V$. cholerae by first binding to TCP and then to the inner membrane/periplasmic TolQRA complex, whereupon the single-stranded DNA [(+) ssDNA] loses its protein coat and is transported into the cytoplasm. (b) The replicative or plasmid form of CTX $\varphi$ (pCTX) is generated when DNA complementary to the phage genome is synthesized. (c) pCTX integrates site-specifically into the $V$. cholerae difregion of chromosome I. Integration requires the phage-encoded RstB protein as well as the host-encoded recombinases XerC and XerD. This recombination occurs between homologous sequences on CTX $\phi$ and the chromosome, which are depicted as red triangles. (d) CTX $\phi$ usually integrates as tandem prophages. (e) Tandem prophages serve as a template to generate extrachromosomal $(+)$ ssDNA. This process requires RstA. (f) RstA also produces (+) ssDNA from pCTX. (g) The phage coat and secretion proteins are expressed from pCTX. (h) and (i) The phage proteins are localized to the inner membrane prior to forming virions. The $(+)$ ssDNA is thought to be simultaneously packaged into phage particles and secreted from the cell. Secretion of CTX $\phi$ from the bacterial cell occurs through the host-encoded EpsD channel.

results in a profuse diarrhea, favoring the dissemination of the bacterium and therefore the phage. The lysogenic form of stable CTX $\phi$ in $V$. cholerae, and the replication of phage does not cause $V$. cholerae cell lysis; therefore, the CTX $\phi$ genome can be vertically and horizontally transferred [17] [24].

\section{5. СТХ $\Phi$ and TCP}

Bacteriophages can convert their bacterial host from a non-pathogenic strain through a process called phage conversion, providing phage-encoded virulence genes to the host. Toxigenic $V$. cholerae isolated carry the ctx AB genes encoded by lysogenic filamentous phage CTX $\phi$ [17]. Only strains that carry CTX $\phi$ cause 
the epidemic and the cholera pandemic. Phage is similar in size, structure, and gene order in filamentous coliphages such as E. coli M13 and f1 [24]. The ctxAB genes that encode the enterotoxin CT type A-B reside in the CTX $\phi$ genome that exists as a prophage in the integrated form of the phage genome in the host of the bacterial chromosome [26]. The ability of V. cholerae strains to cause chole$\mathrm{ra}$ in humans depends on the presence in their genomes of two sets of genes called pathogenicity islands [17]. The first, called the Coregulated Pilus Toxin (TCP), contains the genes responsible for the synthesis of factors allowing the colonization of the mucosa by $V$. cholerae [27]. The genes contained in TCP code in particular for the synthesis of bacterial filaments promoting the adhesion of the bacterium to human intestinal cells [28]. Some authors have shown that this islet of pathogenicity is actually the genome of one called VPI $\phi$, which is transmitted from one $V$. cholerae to another [17].

\section{Diversity of CTX $\Phi$}

The CTX $\phi$ rstR gene sequence can vary considerably among El Tor, classical and isolated 0139, although rstA and rstB show a high level of conservation of the sequence among different $V$. cholerae isolated. The variation of the rstR sequence was used to classify CTX $\phi$. For example, CTX $\phi$ of isolated classics carry rstR class and are designated CTXclass $\phi$; while El Isolated Tor usually carry rstR ET, and are CTXET $\phi$. V. cholerae 0139 carries CTXET or a CTX $\phi$ with a distinct rstR designated rstRCalc and the phage is designated CTXCalc $\phi$ [11] [29]. $V$. cholerae 0139 strains may also carry CTXET $\phi$ or both CTXcalc $\phi$ prophages simultaneously [24]. In addition several new rstR sequences have been identified in $V$. cholerae non 01/non-0139 isolated, and from which there may be various CTX $\phi$ carry by these strains of $V$. cholerae from the environment [30]. The evolutionary molecular analysis of CTX $\phi$ s derived from a variety of isolated natural $V$. cholerae was made, based on sequence analysis of rstR and gIIICTX. These data taken together indicate distinct CTX $\phi$ lineages, independent acquisition of CTX $\phi$ by the individual isolated $V$. cholerae, and the novel CTX $\phi$ acquisition by the classical strains, El Tor and 0139 [25] [31].

\section{Epidemiological Situation of Cholera in 2011}

In 2011, cases of cholera caused by Vibrio cholerae were reported in all regions of the world. In total, 58 countries reported a cumulative total of 5,898,541 cases, including 7816 deaths, or a case-fatality rate (LT) of $1.3 \%$, which represents an $85 \%$ increase in the number of cases compared to last year. For the second year in a row, the proportion of cases reported by Africa was less than $50 \%$ of the global total (Figure 1). The increase in the number of cases worldwide compared to 2010 is the result of a major outbreak that began in October 2010 in Haiti and is still ongoing. As in previous years, the trends and annual figures presented in this report do not take into account an estimated 500,000 to 700,000 annual cases attributed to acute watery diarrhea, which occur in Southeast Asia and Southeast Asia in Central Asia [32] (Figure 2). 


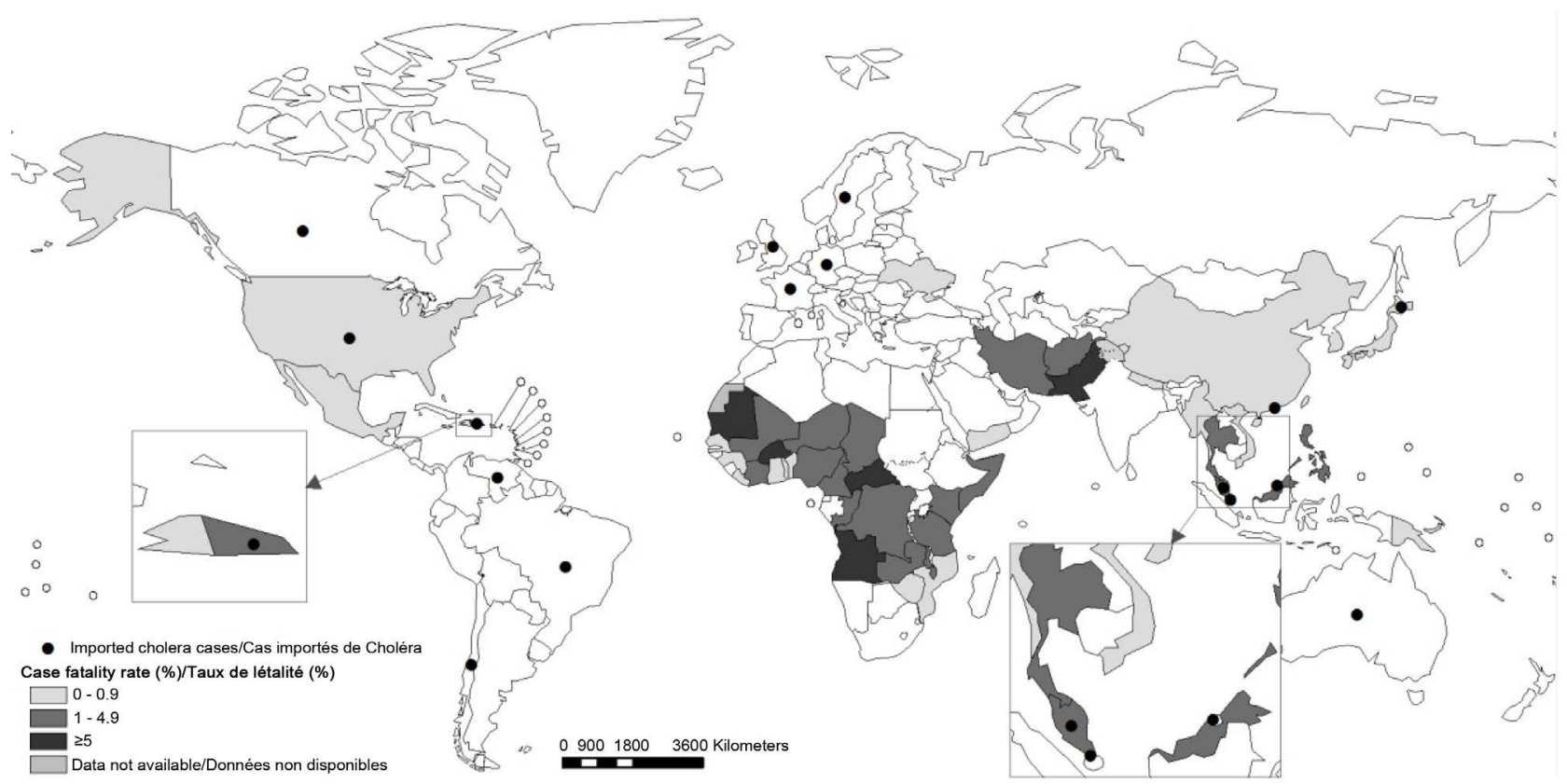

Figure 2. Epidemiology of cholera in the world Source: WHO 2012, http://www.who.int/wer.

\section{Epidemiological Survey of the Democratic Republic of Congo in 2011}

\subsection{Province of Katanga}

In 2011, Katanga reported 3236 cases and 52 deaths from cholera (lethality: $1.6 \%)$. Overall, there is a reduction in the number of cases compared to 2010 when 5245 cases and 104 deaths were reported. For more than 11 years, Katanga Province has continuously reported cases of cholera with two outbreaks at the beginning and end of the year. The lull period (late May to late August), corresponds to the dry season. However, epidemic outbreaks have been observed in the dry season most often following interruptions in the supply of drinking water and also to cyclical movements of populations [33].

\subsection{Province of South Kivu}

According to the central level database, 6389 cases and 35 cholera deaths were reported in 2011. However, the South Kivu database reports 6832 cases with 53 deaths, a difference of 443 cases and 18 deaths. This difference, while not changing the overall evolutionary trend of the epidemic in the province, illustrates late arrivals (weaknesses in readiness) of data from health zones to the province. Often, late arrivals to the provincial epidemiological surveillance office are not always sent centrally to improve reporting completeness. Hence this difference between the bases of the provinces and those of the central level [33].

\subsection{Province of North Kivu}

In 2011, North Kivu reported 5426 cases of cholera and 57 deaths. The high lethality observed over the past three years $(1.1 \%)$ could be explained by popula- 
tion influx and emergence of cases in non- endemic health areas such as Vuhovi where the reported case fatality is $6.3 \%$.. Difficult access to health zones affected by cholera and with a high level of insecurity did not allow rapid implementation of response actions against these epidemics [33].

\subsection{Province of Maniema}

According to the national database maintained in Kinshasa, there would have been very little information on the cholera situation in Maniema in 2011. According to this national database, 13 cases were reported from the health zone of Lubutu. Given the resumption of traffic between the two Kivu and Lubutu, it is possible that the index cases of this Lubutu epidemic came from Kivu [35]. In 2011, this province reported a total of 1638 cases and 74 deaths, a lethality of $4.5 \%$. According to the distribution of cases by health zone, three geographical areas were affected by cholera in Orientale Province [33].

\subsection{Province of Ecuador}

Despite a very limited supply of drinking water, despite numerous sanitation problems in several ports and markets in the main cities of Ecuador located along the river, this province has remained free from cholera since the end of the last cholera epidemics. 2001. The epidemic reported from April 2011 is a consequence of the spread of cholera cases from the health zones affected by this disease in Orientale Province. This epidemic restart proves the epidemic nature of Ecuador's health zones. Also, it would be logical to think that the end of the current epidemics in Ecuador (and in other western provinces) should only be declared when it is reported that there are zero cases of cholera [33].

\subsection{Province of Bandundu}

The 2011 Bandundu outbreaks (first cases at week 22) are also the result of the spread of Kisangani epidemics across the river. Bandundu province reported in 2011, 1664 cases and 137 deaths due to cholera a lethality of $8.2 \%$. The Bolobo Health Zone (1325 cases and 62 deaths, or $4.7 \%$ lethality) reported $60 \%$ of all cases in the province [33].

\subsection{Province of Kinshasa}

In the more recent past, the latest cholera outbreaks in the city-province of Kinshasa dates back to 1996 to 2001. In 2011, the first cases of cholera were reported in Kinshasa from June 12 (week 24). Until week 52, 937 cases and 19 deaths were reported, a lethality of $2 \%$. The health zones of Kingabwa and Maluku I were the first to be affected by week 24 . The index cases were merchants who arrived by boat from the health zones of Kwamouth and Bolobo (Bandundu province). Kingabwa, Limete and Maluku I, the three health zones located along the river and with intense port activity in connection with the Bandundu localities along the river, reported $67 \%$ of all cases in Kinshasa [33].

Table 1 and Table 2, demonstrates The Fungurume area in Lualaba province 
Table 1. Presents the epidemiological situation of cholera in 2017, S-48.

\begin{tabular}{|c|c|c|c|c|c|c|c|c|c|}
\hline Province & CaseS1- S48 & $\begin{array}{c}\text { Lethality } \\
\text { S1-S48 (\%) }\end{array}$ & Case S46 & Case S47 & Case $\$ 48$ & $\begin{array}{c}\text { Lethality } \\
\text { S48 }\end{array}$ & $\begin{array}{c}\text { Number of } \\
\text { affected } \\
\text { areas S48 }\end{array}$ & $\begin{array}{c}\text { TV } \\
\text { S47_S48 } \\
(\%)\end{array}$ & $\begin{array}{l}\text { New Zones } \\
\text { assigned } \\
\text { to S48 }\end{array}$ \\
\hline Lomami & 1941 & 5.8 & 430 & 345 & 223 & 2.6 & 4 & -35.4 & - \\
\hline Nord-Kivu & 13,341 & 0.7 & 405 & 398 & 210 & 0.4 & 6 & -47.2 & - \\
\hline Sud-Kivu & 11,299 & 0.4 & 383 & 359 & 197 & 0 & 9 & -45.1 & - \\
\hline Haut Lomami & 4269 & 1.9 & 121 & 165 & 166 & 0 & 7 & 0.6 & - \\
\hline Kasaï & 654 & 7.8 & 133 & 102 & 78 & 14.1 & 5 & -23.5 & - \\
\hline Kongo Central & 3994 & 2.5 & 112 & 104 & 66 & 7.5 & 5 & -36.5 & Mbanzangungu \\
\hline Sankuru & 351 & 12.2 & 146 & 112 & 50 & 8 & 2 & -55.4 & - \\
\hline Tanganyika & 5999 & 2 & 85 & 88 & 46 & 0 & 5 & -47.7 & - \\
\hline Ituri & 1210 & 4.6 & 23 & 46 & 35 & 0 & 4 & -23.9 & - \\
\hline Lualaba & 87 & 4 & 16 & 6 & 31 & 0 & 1 & 416.7 & - \\
\hline Maniema & 1725 & 2.5 & 19 & 12 & 28 & 7.1 & 5 & 133.3 & - \\
\hline Kinshasa & 417 & 7.6 & 2 & 3 & 4 & 0 & 3 & 33.3 & 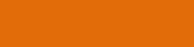 \\
\hline Kwilu & 661 & 6.9 & 15 & 4 & 2 & 0 & 2 & -50.0 & - \\
\hline Equateur & 933 & 4.2 & 3 & 1 & 1 & 0 & 1 & 0.0 & - \\
\hline Kasai Oriental & 10 & 16.7 & 6 & 4 & 0 & 0 & 0 & -100.0 & - \\
\hline $\begin{array}{c}\text { Mai } \\
\text { Ndombe }\end{array}$ & 985 & 5.2 & 6 & 0 & & - & & - & - \\
\hline Haut Katanga & 134 & 6 & 3 & 0 & & - & & - & - \\
\hline Bas-Uele & 362 & 3 & 0 & 0 & & - & & - & \\
\hline Kwango & 1 & 0 & 0 & 0 & & - & & - & - \\
\hline Mongala & 1378 & 6 & 0 & 0 & & - & & - & - \\
\hline Nord Ubangi & 1 & 0 & 0 & 0 & & - & & & - \\
\hline $\begin{array}{c}\text { Sud } \\
\text { Ubangi }\end{array}$ & 1 & 0 & 0 & 0 & & & & - & - \\
\hline Tshopo & 754 & 7.2 & 0 & 0 & & - & & - & - \\
\hline Total & 50,507 & $2.1 \%$ & 1908 & 1749 & 1137 & 2.6 & 59 & -35 & 1 \\
\hline
\end{tabular}

recorded the largest increase in the number of reported cases followed by health zones in the city of Kindu in Maniema. The persistence of households with high transmission potential in Upper Lomami deserves a special investment. The province of Lomami remains in the lead in terms of reported cases even if the overall trend remains down (35\%) compared to week 47 . the positive aspect to consider is the absence of new areas affected. which reflects a stabilization of the old homes (Ngandajika, Kanda Kanda, Mulumba, Kalambay).

Source: National Program for the Elimination of Cholera and Diarrheal Disease Control in the DRC, S-48 2017, Ministry of Public Health [34]. 
Table 2. Presents the epidemiological situation of cholera, Province, DRC, health zones assigned to S-48/2017.

\begin{tabular}{|c|c|c|c|c|}
\hline Province & Case 48 & $\begin{array}{c}\text { Number of } \\
\text { affected areas/S48 }\end{array}$ & TV S 47_48 (\%) & Affected areas \\
\hline Lomami & 223 & 4 & -35.4 & $\begin{array}{l}\text {-Ngandajika, Kanda Kanda, Mulumba, } \\
\text { Kalambay }\end{array}$ \\
\hline Nord-Kivu & 210 & 6 & -47.2 & $\begin{array}{l}\text { Goma, Karisimbi, Nyiragongo, Kirothe, Masisi, } \\
\text { Mweso }\end{array}$ \\
\hline Sud-Kivu & 197 & 9 & -45.1 & $\begin{array}{l}\text {-Bagira, Kadutu, Ibanda, Minova, Idjwi, Katana, } \\
\text { Kabaea, Fizi, Miti Murheza }\end{array}$ \\
\hline Haut Lomami & 166 & 7 & 0.6 & $\begin{array}{l}\text { Mulongo, MalembaNkuku, Bukama, Mukanga, } \\
\text { Kabondodianda, Kikondja, Lwamba }\end{array}$ \\
\hline Kasai & 78 & 5 & -23.5 & -Ilebo, Mikope, Mushenge, Dekesse, Bulape \\
\hline Kongo Central & 66 & 5 & -36.5 & $\begin{array}{l}\text {-Mbanzangungu, Kimpese, KwiluNgongo, } \\
\text { Kimpangu, Ngidinga }\end{array}$ \\
\hline Sankuru & 50 & 2 & -55.4 & BenaDibele, Kole \\
\hline Tanganyka & 46 & 5 & -47.7 & $\begin{array}{l}\text {-Kalemie, } \\
\text { Nyemba, Ankoro, Kongolo, Kabalo }\end{array}$ \\
\hline Ituri & 35 & 4 & -23.9 & $\begin{array}{l}\text {-Fataki, Drodro, } \\
\text { Tchomia, Gethy }\end{array}$ \\
\hline Lualaba & 31 & 1 & 416.7 & -Fungurume \\
\hline Maniema & 28 & 5 & 133.3 & -Kaito, Alunguli, Kampene, Kindu, Kunda \\
\hline Kinshasa & 4 & 3 & 33.3 & -Kingabwa, Limete, Masina I \\
\hline Kwilu & 2 & 2 & -50.0 & -Ipamu, Mokala \\
\hline Equateur & 1 & 1 & 0.0 & -Lukolela \\
\hline Kasaï Oriental & 0 & 0 & -100.0 & - \\
\hline Total $(n=14)$ & 1137 & 59 & $-35 \% /$ to $\mathrm{S} 47$ & - \\
\hline
\end{tabular}

\subsection{Cities and Lakeside Areas of Particular Interest for the Fight against Cholera in the DRC}

The zones (in red) were identified from analyzes of the spatio-temporal dynamics of the epidemics that occurred in eastern DRC between 2000 and 2007. It has been shown that all the epidemics that occurred in this eastern region of the DRC all have their starting point in these seven regions, all lacustrine. During periods of epidemic lull (often in the dry season), cholera cases persist in these areas considered as "sources" of cholera in the DRC. Hence the priority targeting of these areas in the DRC cholera elimination plan [35] (Figure 3).

\section{Conclusion}

Cholera infection is a major challenge for the Democratic Republic of Congo. In order to put an end to this epidemic, hygiene measures must be taken into account to sensitize the population who continues to expose themselves through certain practices. Molecular epidemiology remains a key area to carry out studies related to resistance to anti-infective but also the ongoing monitoring of strains that could come from one region to another. 


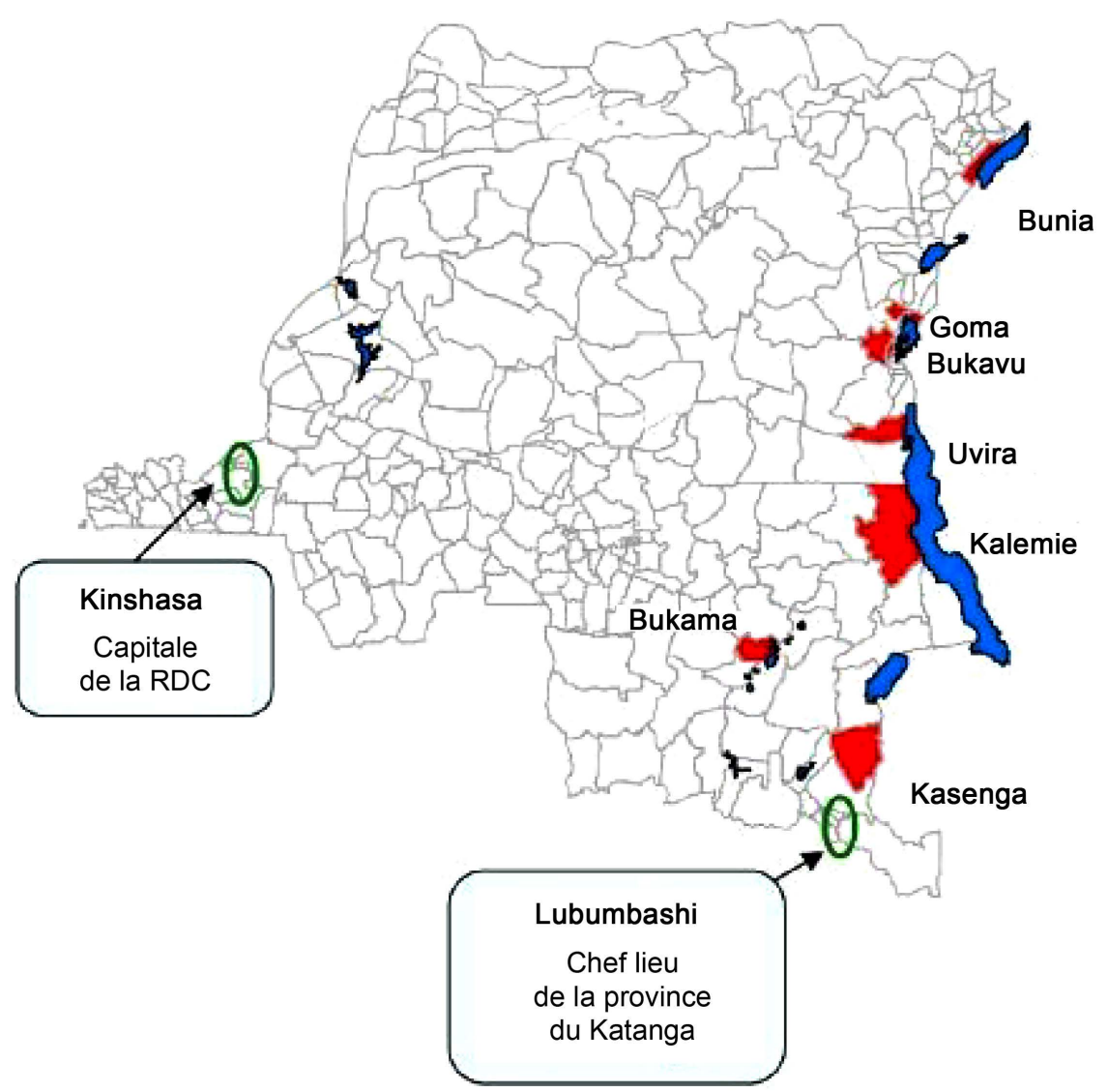

Figure 3. In red, the endemic areas of cholera. Source: multisectoral strategic plan for the elimination of cholera in the DRC 2013-2017, ministry of public health.

\section{Conflicts of Interest}

The authors declare no conflicts of interest regarding the publication of this paper.

\section{References}

[1] Farmer, P., Almazor, C.P., Bahnsen, E.T., Barry, D., Bazile, J., Bloom, B.R., Bose, N., Brewer, T., Calderwood, S.B., Clemens, J.D., Cravioto, A., Eustache, E., Jerome, G., Gupta, N., Harris, J.B., Hiatt, H.H., Holstein, C., Hotez, P.J., Ivers, L.C., Kerry, V.B., Koenig, S.P., Larocque, R.C., et al. (2011) Meeting Cholera's Challenge to Haiti and the World: A Joint Statement on Cholera Prevention and Care. PLoS Neglected Tropical Diseases, 5, e1145. https://doi.org/10.1371/journal.pntd.0001145

[2] Sedas, V.T. (2007) Influence of Environmental Factors on the Presence of Vibrio cholera in the Marine Environment: A Climate Link. The Journal of Infection in Developing Countries, 1, 224-241. https://doi.org/10.3855/jidc.359

[3] Kanungo, S., Tsuzuki, A., Deen, J.L., Lopez, A.L., Rajendran, K., Manna, B., Sur, D., Kim, D.R., Gupta, V.K., Ochiai, R.L., Ali, M., von, S.L., Bhattacharya, S.K. and Clemens, J.D. (2010) Use of Verbal Autopsy to Determine Mortality Patterns in an Urban Slum in Kolkata, India. Bulletin of the World Health Organization, 88, 667-674. https://doi.org/10.2471/BLT.09.073742

[4] Mason, P.R. (2009) Zimbabwe Experiences the Worst Epidemic of Cholera in Africa. The Journal of Infection in Developing Countries, 3, 148-151. 
https://doi.org/10.3855/jidc.62

[5] Das, S., Choudhry, S., Saha, R., Ramachandran, V.G., Kaur, K. and Sarkar, B.L. (2011) Emergence of Multiple Drug Resistance Vibrio cholera O1 in East Delhi. The Journal of Infection in Developing Countries, 5, 294-298.

https://doi.org/10.3855/jidc.1251

[6] Cholera, A.P., News (2007) Last Update on 30/09/2007. Trop. Med., 1.

[7] Zinaka, Y. and Carpenter, Jr. (1972) An Enterotoxin Produced by No Cholera Vibrios. The Johns Hopkins Medical Journal, 131, 403-411.

[8] Tobin D'angelo, M., Smith, A.R., Bulens, S.N., et al. (2008) Severe Diarrhea Caused by Cholera Toxin Producing Vibrio Cholera Serogroup O75 Infections Acquired in the South Eastern United States. Clinical Infectious Diseases, 47, 1035-1040. https://doi.org/10.1086/591973

[9] Dalsgaard, A., Serichantalergs, O., Forslund, A., Lin, W., Mekelanos, J., Mintz, E., Shimada, T. and Well, J.G. (2001) Clinical and Environmental Isolates of Vibrio Cholera Serogroup O141 Carry the CTX Phage and the Genes Encoding the Toxin Coregulated Pili. Journal of Clinical Microbiology, 39, 4036-4092.

https://doi.org/10.1128/JCM.39.11.4086-4092.2001

[10] Jongsik, C., Christopher, J.G., Nur, A.H., Je, H.L., Seon, Y.C., Bradd, J.H., Elisa, T., Yoon, S.J., Dong, W.K., Jae, H.L., Thomas, S.B., David, C.B., Jean, F.C., Chris, J.D., Cliff, S.H., Christine, A.M., Olga, C., Linda, M., Elizabeth, S., Ronald, A.W., Anwar, H., Balakrish, G.N. and Rita, R.C. (2009) Comparative Genomics Reveals Mechanism for Short-Term and Long-Term Clonal Transitions in Pandemic Vibrio cholerae. Proceedings of the National Academy of Sciences of the United States of America, 106, 15442-15447. https://doi.org/10.1073/pnas.0907787106

[11] Nair, G.B., Faruque, S.M., Bhuiyan, N.A., Kamruzzaaman, M., Siddique, A.K. and Sack, D.A. (2002) New Variants of Vibrio cholerae O1 Biotype El Tor with Attributes of the Classical Biotype from Hospitalized Patients with Acute Diarrheal in Bangladesh. Journal of Clinical Microbiology, 40, 3296-3299. https://doi.org/10.1128/JCM.40.9.3296-3299.2002

[12] Faruque, S.M., Tam, V.C., Chowdhury, N., Diraphat, P., Dziejman, M., Heidelberg, J.F., Clemens, J.D., Mekelanos, J.J. and Nair, G.B. (2007) Genomic Analysis of the Mozambique Strain of Vibrio cholerae O1 Reveals the Origin of El tor Strains Carrying Classical CTX Prophage. Proceedings of the National Academy of Sciences of the United States of America, 104, 5151-1516.

https://doi.org/10.1073/pnas.0700365104

[13] Nair, G.B., Qadri, F., Holmgren, J., et al. (2006) Cholera Due to Altered El Tors Trains of Vibrio cholerae O1 in Bangladesh. Journal of Clinical Microbiology, 44, 4211-4213. https://doi.org/10.1128/JCM.01304-06

[14] Bhabatosh, D., Julien, B. and François, X.B. (2011) Molecular Mechanism of Acquisition of the Cholera Toxingenes. Indian Journal of Medical Research, 133, 195-200.

[15] Guidolin, A. and Manning, P.A. (1987) Genetics of Vibrio Cholerae and Its Bacteriophages. Microbiological Reviews, 51, 285-298.

[16] Faruque, S.M., Islam, M.J., Ahmad, Q.S., Faruque, A.S., Sack, D.A., Nair, G.B., Mekalanos, J.J. (2005) Self-Limiting Nature of Seasonal Cholera Epidemics: Role of Host-Mediated Amplification of Phage. Proceedings of the National Academy of Sciences of the United States of America, 102, 6119-6124. https://doi.org/10.1073/pnas.0502069102

[17] Waldor, M.K. and Mekalanos, J.J. (1996) Lysogenic Conversion by a Filamentous Phage Encoding Cholera Toxin. Science, 272, 1910-1914. 
https://doi.org/10.1126/science.272.5270.1910

[18] Kimsey, H.H., Nair, G.B., Ghosh, A. and Waldor, M.K. (1998) Diverse CTXphis and Evolution of New Pathogenic Vibrio cholerae. The Lancet, 352, 457-458. https://doi.org/10.1016/S0140-6736(05)79193-5

[19] Val, M.E., El Kennedy, S.P., Karoui, M., Bonné, L., Chevalier, F. and Barre, F.X. (2008) FtsK-Dependent Dimer Resolution on Multiple Chromosomes in the Pathogen Vibrio cholera. PLoS Genet, 4, e1000201. https://doi.org/10.1371/journal.pgen.1000201

[20] Lencer, W.I. andTsai, B. (2003) The Intracellular Voyage of Cholera Toxin: Going Retro. Trends in Biochemical Sciences, 28, 639-645. https://doi.org/10.1016/j.tibs.2003.10.002

[21] Davis, B.M. and Waldor, M.K. (2002) Mobile Genetic Elements and Bacterial Pathogenesis. American Society for Microbiology Press, Washington DC, 1040-1059. https://doi.org/10.1128/9781555817954.ch45

[22] Ochman, H., Lawrence, J.G. and Groisman, E.A. (2000) Lateral Gene Transfer and the Nature of Bacterial Innovation. Nature, 405, 299-304.

https://doi.org/10.1038/35012500

[23] Boyd, E.F., Heilpern, A.J. and Waldor, M.K. (2000) Molecular Analyses of a Putative CTXphi Precursor and Evidence for Independent Acquisition Distinct CTX (w) s by Toxigenic Vibrio cholerae. Journal of Bacteriology, 182, 5530-5538.

https://doi.org/10.1128/JB.182.19.5530-5538.2000

[24] Boyd, F. (2008) Filamentous Phages of Vibrio cholerae. In: Faruque, S. and Nair, G.B., Eds., Vibriocholerae: Genomics and Molecular Biology, Horizon Scientific Press, UK, 49-66.

[25] Jensen, M.A., Faruque, S.M., Mekalanos, J.J. and Levin, B.R. (2006) Modeling the Role of Bacteriophage in the Control of Cholera Outbreaks. Proceedings of the National Academy of Sciences of the United States of America, 103, 4652-4657. https://doi.org/10.1073/pnas.0600166103

[26] Shah, M.F. and Mekalanos, J.J. (2012) Phage-Bacterial Interactions in the Evolution of Toxygenic Vibrocholerae. Virulence, 3, 7. https://doi.org/10.4161/viru.22351

[27] Faruque, S.M. and Mekalanos, J.J. (2003) Pathogenicity Islands and Phages in Vibrio cholerae Evolution. Trends in Microbiology, 11, 505-510. https://doi.org/10.1016/j.tim.2003.09.003

[28] Karaolis, D.K., Johnson, J.A., Bailey, C.C., Boedeker, E.C., Kaper, J.B. and Reeves, P.R.A. (1998) Vibrio cholerae Pathogenicity Island Associated with Epidemic and Pandemic Strains. Proceedings of the National Academy of Sciences of the United States of America, 95, 3134-3139. https://doi.org/10.1073/pnas.95.6.3134

[29] Davis, B.M., Kimsey, H.H., Chang, W. and Waldor, M.K. (1999) The Vibrio cholerae O139 Calcutta Bacteriophage CTXphi Is Infectious and Encodes a Novel Repressor. Journal of Bacteriology, 181, 6779-6787.

[30] Faruque, S.M., Chowdhury, N., Kamruzzaman, M., Ahmad, Q.S., Faruque, A.S., et al. (2003) Reemergence of Epidemic Vibrio cholera O139, Bangladesh. Emerging Infectious Diseases, 9, 1116-1122. https://doi.org/10.3201/eid0909.020443

[31] Bhattacharya, T., Chatterjee, S., Maiti, D., Bhadra, R.K., Takeda, Y., Nair, G.B., et al. (2006) Molecular Analysis of the rstR and orfU Genes of the CTX Prophages Integrated in the Small Chromosomes of Environmental Vibrio cholera non-O1, non-O139 Strains. Environmental Microbiology, 8, 526-634.

https://doi.org/10.1111/j.1462-2920.2005.00932.x 
[32] WHO (2012) Weekly Epidemiological Record. http://www.who.int/wer

[33] Ministry of Public Health, General Secretariat (2012) Epidemiological Situation of Cholera in the Democratic Republic of Congo in 2011. Cellule de SUM du plan stratégique d'élimination du Choléra en RDC, 25, 27-28, 31, 33-34.

[34] Ministry of Public Health, General Secretariat (2017) Epidemiological Situation of Cholera in the Democratic Republic of Congo, Week 48. National Program for the Elimination of Cholera and Diarrheal Disease Control in the DRC. 4-5.

[35] Ministry of Public Health, General Secretariat (2013) Multisectoral Strategic Plan for the Elimination of Cholera in the Democratic Republic of Congo 2013-2017. 21 p. 